IZA DP No. 10277

Spatial Segregation and Socio-Economic Mobility in European Cities

Maarten van Ham

Tiit Tammaru

Elise de Vuijst

Merle Zwiers

October 2016 


\title{
Spatial Segregation and Socio-Economic Mobility in European Cities
}

\author{
Maarten van Ham \\ Delft University of Technology, \\ University of St Andrews and IZA
}

Tiit Tammaru

University of Tartu

\section{Elise de Vuijst}

Delft University of Technology

\author{
Merle Zwiers \\ Delft University of Technology
}

\section{Discussion Paper No. 10277 \\ October 2016}

\author{
IZA \\ P.O. Box 7240 \\ 53072 Bonn \\ Germany \\ Phone: +49-228-3894-0 \\ Fax: +49-228-3894-180 \\ E-mail: iza@iza.org
}

\begin{abstract}
Any opinions expressed here are those of the author(s) and not those of IZA. Research published in this series may include views on policy, but the institute itself takes no institutional policy positions. The IZA research network is committed to the IZA Guiding Principles of Research Integrity.

The Institute for the Study of Labor (IZA) in Bonn is a local and virtual international research center and a place of communication between science, politics and business. IZA is an independent nonprofit organization supported by Deutsche Post Foundation. The center is associated with the University of Bonn and offers a stimulating research environment through its international network, workshops and conferences, data service, project support, research visits and doctoral program. IZA engages in (i) original and internationally competitive research in all fields of labor economics, (ii) development of policy concepts, and (iii) dissemination of research results and concepts to the interested public.
\end{abstract}

IZA Discussion Papers often represent preliminary work and are circulated to encourage discussion. Citation of such a paper should account for its provisional character. A revised version may be available directly from the author. 


\section{ABSTRACT \\ Spatial Segregation and Socio-Economic Mobility in European Cities $^{1}$}

Income inequality is increasing in European cities and this rising inequality has a spatial footprint in cities and neighbourhoods. Poor and rich people are increasingly living separated and this can threaten the social sustainability of cities. Low income people, often with an ethnic minority background, can get cut off from important social networks and mainstream society, and this can lead to social unrest. Increasing inequality and socio-economic segregation is therefore a major concern for local and national governments. Socio-economic segregation is the outcome of a combination of inequality and poverty, and the spatial organisation of urban housing markets. Poverty, and living in poverty concentration neighbourhoods is transmitted between generations and neighbourhood poverty is reproduced over time through to the residential mobility behaviour of households. Urban policy often focusses on reducing segregation through physical measures in cities, such as demolishing houses in deprived neighbourhoods and replacing them with housing for the middle classes. Such policies will not solve the underlying causes of segregation, but only redistribute poverty over cities. Policy initiatives should first of all focus on reducing inequality by creating equal opportunities for people and invest in education and training. Inclusive growth strategies should combine both people-based and area-based policy measures.

JEL Classification: D63, D64, I32, J62, P36, P46, R23

Keywords: $\quad$ socio-economic segregation, neighbourhood change, cities, Europe, residential mobility, social mobility, intergenerational mobility

Corresponding author:

Maarten van Ham

OTB - Research for the Built Environment

Faculty of Architecture and the Built Environment

Delft University of Technology

P.O. Box 5030

2600 GA, Delft

The Netherlands

E-mail: m.vanham@tudelft.nl

\footnotetext{
${ }^{1}$ This working paper was commissioned by the OECD and part of the text was used for the 2016 OECD report Making Cities Work for All. Data and Actions for Inclusive Growth (https://www.oecd.org/regional/makingcities- work-for-all-9789264263260-en.htm).
} 


\section{Introduction}

Income inequality has been increasing in many countries in the last decades; the gap between the rich and poor is at its highest in 30 years (OECD, 2015). Although there are differences in the timing, intensity and directions of changes across countries (OECD, 2008) generally speaking higher income groups have benefited more from economic growth than lower income households. Especially people with skills have seen their incomes rise, while those without skills have not kept up (OECD, 2015). Rising inequality in incomes and wealth (see also Pikety, 2013) is a major concern because it also influences inequality in other life domains such as education, health, life expectancy, or employment prospects. Inequality can harm the social stability of societies, and reduce trust in governments and institutions, and could even put at risk democratic processes as lower income groups become disengaged with politics (OECD, 2015).

Inequality has a clear spatial footprint in our cities, where rich and poor people often live segregated in different neighbourhoods (Tammaru et al., 2016). Although segregation can also be positive, it is often seen as problematic for individuals, households, neighbourhoods, cities and societies (van Ham et al., 2016). Segregation is deemed to be especially problematic when it is involuntary. Most higher income households have some level of freedom in which neighbourhoods to live, while low income households have much less options, and often end up in those places where housing is cheap and accessible. Socio-economic segregation is largely a consequence of inequality and poverty. The extent to which inequality leads to spatial segregation is strongly related to welfare and housing market systems, and to the spatial organisation of the urban housing market (van Ham et al., 2016). In many cities low cost (owner-occupied, private or socially rented) housing is spatially clustered in certain neighbourhoods. This is especially the case in large unattractive high-rise estates from the 1960s and 1970s. It is often in such neighbourhoods where low income households end up living because they cannot afford to live elsewhere. Also higher income households segregate, in fact, higher income households live more segregated than low income households. This is because high income households have a larger choice set of where to live (van Ham et al., 2016).

The international comparative study Socio-Economic Segregation in European Capital Cities. East Meet West ${ }^{2}$ (Tammaru et al. 2016) shows that socio-economic segregation has increased in many European cities since 2001. The study compares levels of socio-economic segregation in 2001 with that of 2011 in twelve European cities: Madrid, Tallinn, London, Stockholm, Vienna, Athens, Amsterdam, Budapest, Riga, Vilnius, Prague and Oslo (in order of decreasing levels of segregation). The conclusion is that socio-economic segregation has increased in almost all of these cities. To put this in perspective it is important to mention that segregation in European cities is still relatively low compared to cities in, for example, Asia or North America. The comparative study identifies rising inequality as a major cause of increasing segregation and argues that a high level of segregation can undermine the social stability of cities. The riots in Paris (2005), London (2011) and Stockholm (2013) cannot be seen separate from high concentrations of poverty in these cities, often in combination with high levels of ethnic segregation (Tammaru et al., 2016).

Generally speaking, the socio-economic status of neighbourhoods changes relatively slowly over time (Zwiers et al., 2016), and the urban mosaic of neighbourhoods by income remains rather stable. Off course there are exceptions with neighbourhoods showing rapid decline, or upgrading due to gentrification or urban renewal policies. Urban renewal of

\footnotetext{
${ }^{2}$ This first half of this essay is based on the Tammaru et al., 2016 book and other papers and summaries written by different combinations of the editors of the book. All sources are given credit in the list of references and with in-text references, although quotation marks are not used.
} 
deprived neighbourhoods often involves demolition and new construction of dwellings, and replacing part of the original population. The main drivers of neighbourhood change are insitu change of sitting households (such as getting and losing jobs) and selective inflow and outflow of residents. When just above average income households leave a neighbourhood and they are replaced by low income households, this can lead to a higher concentration of poverty in certain neighbourhoods. Neighbourhoods tend to reproduce themselves over time in terms of their socio-economic composition due to the selective mobility behaviour of households (Hedman et al., 2011). Households generally "choose" neighbourhoods with people who are very similar to themselves. Poverty, and living in poverty neighbourhoods, is also reproduced over time between generations. The children of low income households often end up in neighbourhoods which are very similar to the neighbourhoods where they lived with their parents (van Ham et al., 2014; de Vuijst et al., 2015). This is especially the case for those belonging to non-Western ethnic minority groups.

This paper will discuss the increasing socio-economic segregation in European cities, with a specific focus on intergenerational transmission of poverty and living in poverty neighbourhoods. First the paper will give a brief overview of some of the literature on segregation, the underlying mechanisms, and common policy interventions related to creating more inclusive cities. Second, the paper will discuss the main findings from the recent study showing that segregation in Europe is increasing. Third, the paper will focus on neighbourhood change over longer periods of time. Fourth, the focus will be on intergenerational transmission of income and neighbourhood status. The final section will give a brief summary of the paper.

\section{Background}

Socio-economic segregation in cities is a symptom of inequality (Tammaru et al., 2016; van Ham et al., 2016). If everyone would earn the same, there would not be segregation of poor and rich people. Although segregation by income is often seen as problematic, this is not necessarily the case. Segregation can also be positive if it is the result of free choice. The most affluent households often live the most segregated as they have the income to choose neighbourhoods of their own preference. But also less affluent households often live segregated by choice. The literature clearly shows that households tend to choose neighbourhoods with people who are very similar to themselves in terms of income, class, ethnicity and religion (Feijten and van Ham, 2009; Schelling 1969, 1971; Clark, 1991). People are not just segregated in residential neighbourhoods, but also in other life domains, such as education and work (van Ham and Tammaru, 2016). Living among similar people can have major benefits as it can reduce conflict, give people a sense of safety, and foster social networks. Living in enclaves with people with similar preferences, needs, and life styles can also have the benefit of shared services and facilities (such as shops, cultural and religious facilities). Another important remark to make is that inequality is not necessarily a problem. There is always some level of inequality in cities. Inequality is a problem when there is a substantial group of people at the bottom of the income distribution with insufficient means to carry the costs of daily life. Poverty is a problem, inequality not necessarily.

So segregation is not necessarily a negative thing, in fact, most people live in quite segregated neighbourhoods. However, more extreme levels of ethnic and socio-economic segregation (these often overlap) are often perceived as undesirable by (local) governments, even more so when such segregation is involuntary. Citizens, but also local and national governments often express concern over increasing inequality and spatial segregation in European cities. There is the risk that when the more affluent and the poor live more and more 
separate lives, this might lead to estrangement and fear for others. This is especially the case when there are very clear spatial borders within cities; such as gated communities for the affluent who separate themselves from the rest of the population, and so-called no-go-areas with extreme concentrations of poverty and high levels of crime. Such extreme spatial separation can lead to social unrest, and even conflict and riots.

There is also a large literature on neighbourhood effects which suggests that living in poverty concentration neighbourhoods can have negative effects on individual outcomes such as health, income, education and general well-being (van Ham et al. 2012). Such effects are thought to especially harm children who grow up in poverty concentration neighbourhoods. Potential causal mechanisms run through socialization effects, negative peer group effects, but also stigma effects, and a lack of social networks to find a job. Also living in neighbourhoods which are spatially cut off from centres of employment are expected to harm the employment prospects of residents. As a result it is thought that living in poverty concentration neighbourhoods can harm the potential of adults and children. Although the evidence for neighbourhood effects is far from conclusive, the strong believe in neighbourhood effects is a reason for concern about increasing levels of socio-economic segregation. These concerns are further fuelled by the fact that socio-economic and ethnic segregation are often strongly connected to each other, and segregation is repeated over multiple life domains. For example, residential segregation is strongly related to workplace segregation (van Ham and Tammaru 2016). There is no simple 1-on-1 relationship, but many first and second generation immigrants from outside the European Union belong to the lowest income groups and live concentrated in the lowest income neighbourhoods of cities. Research clearly shows that, especially for low income non-western ethnic minorities, there is strong intergenerational transmission of living in low income neighbourhoods: children who grow up in low income neighbourhoods are very likely to live in similar low income neighbourhoods as adults (Hedman et al., 2015, see also section 4 of this paper).

Fundamentally the most important cause of socio-economic segregation is income inequality. As mentioned in the introduction, income inequality has increased in the last 30 years. This increase is strongly connected with macro-level factors such as globalisation and restructuring of the labour market (Sassen 1991; Hamnett 1994; Tammaru et al., 2016). There are groups in society which do not benefit from economic growth and who are not able to adapt to a changing economy and labour market, resulting in long term poverty. The extent to which such poverty leads to socio-economic segregation depends on the spatial organisation of the housing market and the housing and welfare systems in each country/city. Cities with strongly spatially concentrated low cost (social) housing are more segregated than cities where low cost housing is spread geographically. The type of welfare and housing market system in a country can either soften or enhance the effects of income inequality (Musterd and Ostendorf 1998). Europe generally has a tradition of strong welfare states compared to the rest of the world (see Esping Andersen 1990), and because of this, the level of segregation in Europe is still low compared to the rest of the world; the most segregated cities in Europe are still less segregated than most major cities in the USA (Florida 2015). Housing market systems are connected to welfare regime types, but there is no 1-to-1 relationship and housing systems also have their own independent effect on levels of segregation. Generally speaking it can be expected that more market involvement in housing contributes to a firmer relation between income disparities and segregation as the lowest income households sort into the cheapest housing stock which is often spatially concentrated in certain neighbourhoods.

\section{Policy responses to segregation}

The policy interventions with regard to socio-economic segregation can be summarised in two categories: place-based policies and people-based policies (van Ham et al. 2012). The place- 
based policies mainly focus on the physical upgrading of deprived neighbourhoods. By demolishing low cost (social) housing and rebuilding more expensive rental and owneroccupied housing the socio-economic mix of households can be influenced. Often these policies are referred to as social mix policies (Atkinson \& Kintrea, 2002; Kearns, 2002; Musterd, 2002). Place-based policies require huge investments, but within a relatively short period of time a neighbourhood can be upgraded by replacing buildings and people. Such policies can only be successful if middle class households can be attracted to deprived neighbourhoods. Place-based policies were very popular up to the start of the financial crisis in 2008, and since then most of the larger initiatives in Europe have ended or have been stopped due to financial constraints.

There is a strong belief that social mix policies also have a positive effect on the original residents of deprived neighbourhoods. The idea is that introducing middle income households in such neighbourhoods will create positive role models and job finding networks. There is no evidence that this is actually the case. Recently, many European media evaluated the current situation in the Paris suburbs which were the stage of the 2005 riots. 10 years after the riots, and despite many billions in investments in these suburbs, little seems to have changed. Newspapers headlined "10 years after the riots, nothing changed" (Chrisafis, 2015) and "it goes better with the stones, but not with the people" (Giesen, 2015). Also in the Netherlands evaluation of large scale urban restructuring comes to similar conclusions: placebased investments have been successful in upgrading buildings and infrastructure, but the people have not benefitted in terms of jobs and income.

People-based policies focus on reducing poverty and creating opportunities for people in the areas of education and employment. People-based policies require a very long term perspective as it might take a generation or longer to reduce (intergenerational) poverty. The success of people-based policies are not always visible in local communities as success might leak away. If people-based policies are successful, then children do well in school and move to higher education, and people might get jobs, more income, and hence a larger choice set on the housing market, and as a result move to a better neighbourhood. The success of such policies might therefore end up in other parts of the urban region, and the people who leave might be replaced by other low income households.

So place-based policies do not necessarily reduce poverty and inequality, and peoplebased policies might not have the desired local effect. In the end segregation is a symptom of inequality and poverty and reducing poverty should be the main aim of policy. The best strategy seems to be a mix of the two policies, tailored at specific neighbourhoods and cities, where neighbourhoods should not be viewed in isolation, but how they function within the larger urban housing and labour markets. Such an urban wide view should also include policies which stimulate intra-urban mobility through public transport, aiming at improving access to jobs and services.

\section{Increasing socio-economic segregation in Europe}

The book Socio-Economic Segregation in European Capital Cities. East Meet West (Tammaru et al., 2016) compares levels of socio-economic segregation in 2001 with that of 2011 in twelve European cities: Madrid, Tallinn, London, Stockholm, Vienna, Athens, Amsterdam, Budapest, Riga, Vilnius, Prague and Oslo (in order of decreasing levels of segregation). The conclusion is that socio-economic segregation has increased in all these cities (see Figure 1), except Amsterdam (which shows a reduction in segregation). 
Figure 1. Index of dissimilarity

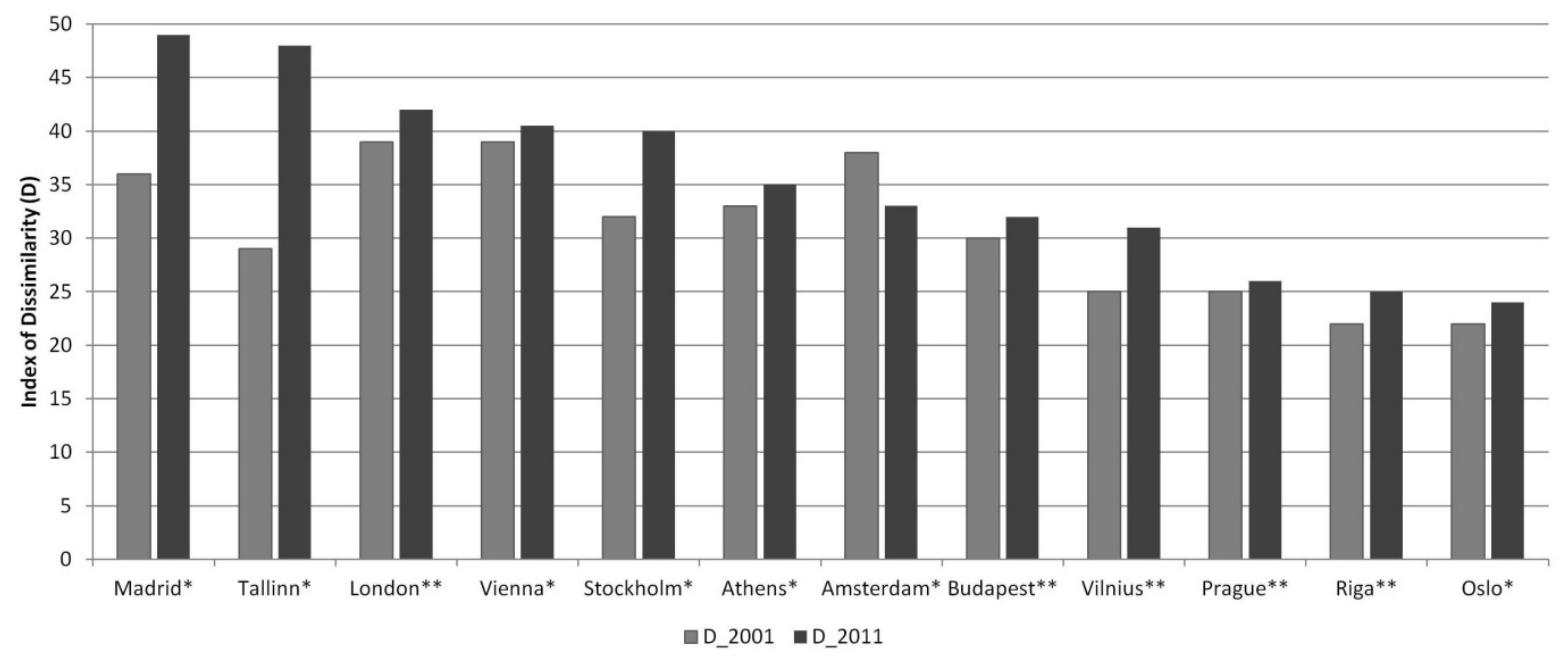

* metropolitan region, defined as travel to work or housing market areas

** city, defined administratively in countries with no comprehensive data for the whole metropolitan region

Madrid, Tallinn, London, Budapest, Vilnius, Athens, Prague, Riga - managers and elementary occupations

Amsterdam, Oslo, Stockholm - highest and lowest income quintile

Vienna - university degree and compulsory education

Source: Marcińczak et al., 2016

The term segregation refers to the physical separation of two or more groups into different neighbourhoods. There are many ways to measure segregation, and the best known measure is the index of dissimilarity. This index can measure the relative separation or integration of socio-economic groups across all neighbourhoods of a city. A socio-economic dissimilarity index of, for example, 40 (comparing poor and rich), would mean that $40 \%$ of poor people would need to move to another neighbourhood to make poor and rich people evenly distributed across all neighbourhoods. The index is calculated as follows:

$$
D=\frac{1}{2} \sum_{i=1}^{n}\left(\frac{h_{i}}{H_{T}}-\frac{l_{i}}{L_{T}}\right) \text {, }
$$

where $n$ is the number of spatial units/neighbourhoods; $h_{i}$ is the number of members of one group (e.g. highest socio-economic group) in neighbourhood $i ; H_{T}$ is the total number of this group members in the city; $l_{i}$ is the number of the other group (e.g. lowest socio-economic group) in neighbourhood $i$; and $L_{T}$ is the total number of this group members in the city. We used the smallest spatial units available in each city that roughly correspond to census tract areas.

Ideally socio-economic segregation was measured in exactly the same way for each city using income data on a very low geographical resolution. But unfortunately such data is not available in many countries. In this study income data for small neighbourhoods was only available for the Netherlands and Sweden. In most of the other countries occupational status data was used, under the assumption that occupational status is a reasonable proxy for income. This is probably the case for lower and higher occupational status jobs, but less so in 
the middle. In one country educational data was used as a proxy for income. Data was analysed for the years 2001 and 2011 because these years correspond with the most recent census dates in Europe. More recent data is not available for most countries. For the Netherlands and Sweden use was made of register data, which is available on a continuous basis and included geo-coded income data. Unfortunately no occupational status data is available for the full population in these register based countries. The choice for the 12 cities (13 are included in the book, but the data is not fully comparable with the other cities) was based on the availability of data and research capacity, and to reflect different geographical regions in Europe and different types of welfare and housing market systems (Tammaru et al., 2016).

Figure 2. Income inequality and residential segregation between top and bottom social categories in selected European cities, 2001/2004-2011.

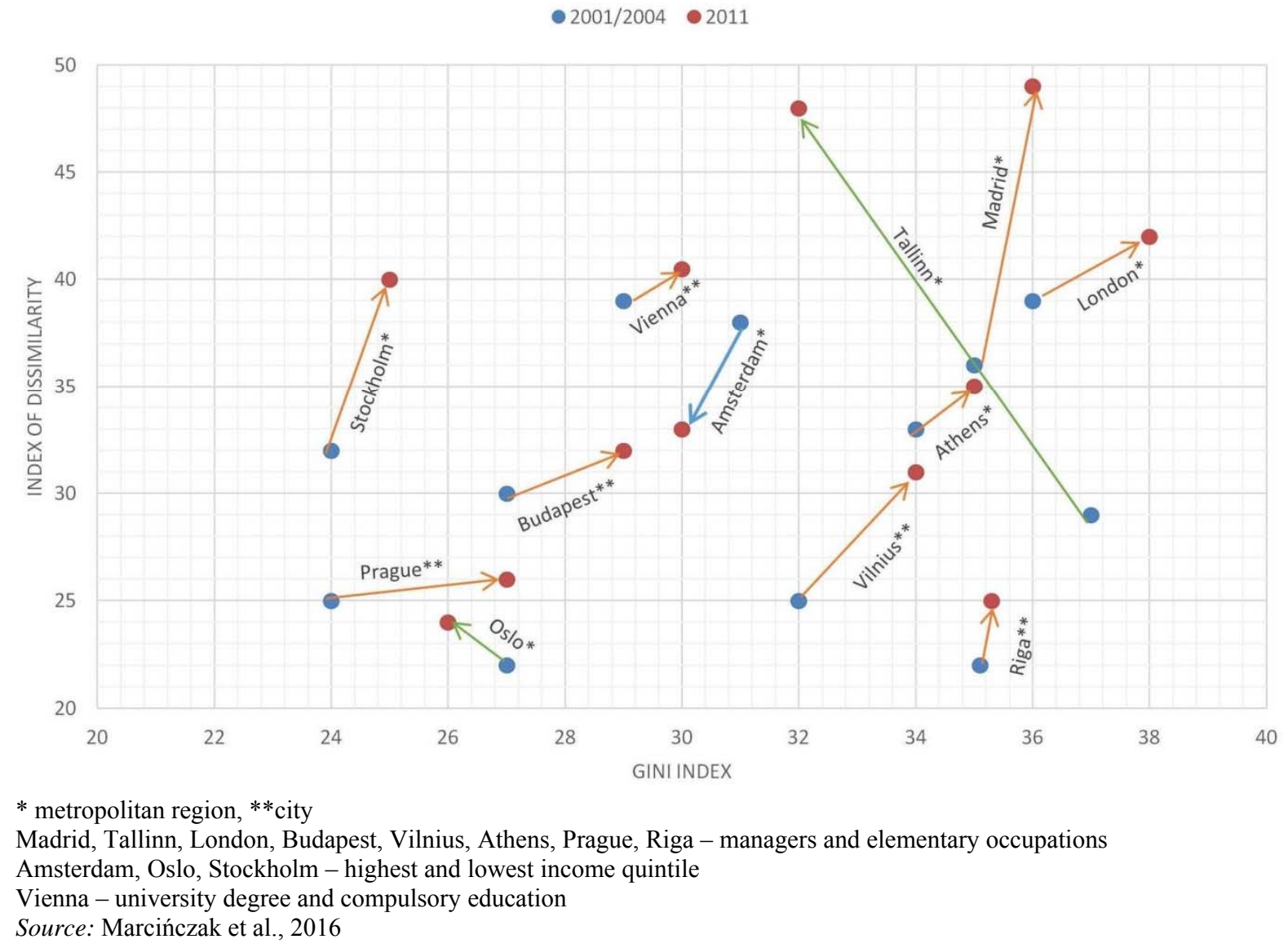

Figure 1 shows the levels of socio-economic segregation in all twelve cities in both 2001 and 2011 (see also Marcińczak et al., 2016). Madrid showed the highest level of segregation in 2011, closely followed by Tallinn and then London. On the other end of the spectrum, Oslo had the lowest level of segregation, followed by Riga and Prague. Madrid, Tallinn and Stockholm showed the strongest increase in socio-economic segregation between 2001 and 2011. Figure 2 gives another perspective on this data by plotting the change in segregation between 2001 and 2011 (using the index of dissimilarity on the y-axis) against the change in the gini index (measure of inequality) between 2001 and 2011 (see also Marcińczak et al., 2016). Figure 2 shows that in most cities an increase in segregation was related to an increase in inequality as would be expected. Oslo and Tallinn are exceptions as in both cases inequality dropped somewhat while segregation increased. In both cases it is expected that the 
rise in segregation is largely due to a rise in inequality a decade before as segregation always follows inequality with a time lag: the urban mosaic is slow to respond to changes in the economy because households do not immediately change their housing situation when they lose income or their jobs. Because of this time lag it can be expected that the effect of the global economic crisis from 2008 has not reached its full extent: it is expected that the level of socio-economic segregation will continue to rise after 2011 due to increasing inequality.

Amsterdam was the only city were segregation decreased between 2001 and 2011. The Amsterdam research team explained the unique situation of their city by referring to the economic crisis and the high share of socially rented dwellings in Amsterdam (Musterd \& van Gent, 2015). During the economic crisis, starting from 2008, many middle income households (some of whom live in social housing) postponed their planned moves to bigger dwellings, which slowed down the long term process of increasing levels of segregation, and even caused neighbourhoods to become more mixed. Towards the end of 2015 it could be seen that more households started to move again, and that house prices in Amsterdam were increasing again rapidly in the most desired areas. This trend is expected to lead to increasing levels of socio-economic segregation in the city.

Madrid showed the highest level of socio-economic segregation in 2011, and the second highest increase in segregation since 2001 (Leal \& Sorando, 2016). The increase in segregation is largely due to a strong increase in inequality in the last ten years and the previous decade. The labour market underwent a dramatic restructuring with a strong increase in the number of professionals on the one hand, and a very strong increase in unemployment levels on the other hand. The professionals concentrated in the nicest parts of the city, leading to a high level of segregation. Unemployment rose quickest in blue-collar worker neighbourhoods.

Of all the twelve cities investigated, Tallinn exhibits the largest growth in socioeconomic segregation (Tammaru et al., 2016). After the collapse of the Soviet Union in the early 90's, Estonia underwent a rapid transition from a centrally controlled state economy to the most market-oriented liberal system in Eastern Europe. After this, social inequality increased rapidly. The government withdrew from the housing market and almost all social housing has now been sold off. Currently only two percent of housing stock is in public hands. The Russian minority population lives largely in pre-fab high rise Soviet era flat districts, especially in the industrial areas bordering Russia. Segregation in Tallinn runs clearly along social and ethnic lines, partly caused by a lack of urban and housing market policies (van Ham et al., 2016). Interestingly, where Tallinn showed some of the highest levels of segregation and also a very high increase in segregation over the last decade, Riga (Bērziņš, \& Krišjāne, 2016) and Vilnius (Valatka et al., 2016) have much lower levels of segregation despite the fact that they underwent similar transitions in their economy and labour market after 1990. The most likely explanation is that Estonia embraced the market system much more and quicker than the other Baltic states, and as a result showed a stronger increase in inequality and hence segregation.

The level of socio-economic segregation in Stockholm was much higher than expected (Andersson \& Kährik, 2016). The increase of segregation was no surprise given that inequality has been increasing in Sweden in the last decades. Sweden is no longer the social paradise it used to be and the liberal political climate of the last decade has made the Swedish economy more market orientated. As a result, investments in public housing have been reduced and efforts to create mixed neighbourhoods have come to a halt. At the same time, Stockholm was confronted with a large inflow of (non-western) immigrants, with largely low incomes who settled in the cheapest parts of the city. Interestingly, the level of segregation in Oslo (Wessel, 2016) is the lowest of the 13 cities while Sweden and Norway share many characteristics. Although the housing market in Oslo is much more market orientated than the 
housing market in Stockholm, segregation levels are low because of generous measures to redistribute wealth and the absence of large spatial concentrations of low cost housing.

A general conclusion from all 12 case studies is that rising inequality has a clear spatial footprint in cities and leads to increasing socio-economic segregation. This rising inequality is related to increasing globalisation and restructuring of the labour market. The extent to which this rising inequality leads to more segregation is related to the types of welfare state and housing systems, and the spatial organisation of urban housing markets. Each city in different in how it responded to rising inequality and in-depth knowledge is needed to understand the patterns observed (see for more detail the city chapters in Tammaru et al., 2016). Another general conclusion from all 12 case studies is that spatial inequality follows socio-economic inequality with a considerable time lag (van Ham et al., 2016). It takes some time before increasing inequality translates into the physical structure of cities. The case of Tallinn shows, that a stronger role for markets (a very liberal welfare regime) considerably speeds up the segregation process as markets sort the rich and the poor into different neighbourhoods, especially when social inequalities are high. The abundance of neighbourhoods with homogenous housing seems to matter, too. For example, the vast modernist housing estates from the post-War period are abundant and socially downgrading both in Tallinn and in Stockholm. The 2001-2011 data covers a large part of the economic crisis since 2008, but the data does not yet show the full effect of the global economic crisis on the spatial sorting of socio-economic groups in European cities. It is expected that in the next 10 years segregation will increase further.

\section{Neighbourhood change and reproduction}

Neighbourhoods are relatively stable over time in their socio-economic population composition, largely due to a static housing stock. The population composition of a neighbourhood can change due to socio-economic and demographic changes among the sitting population and due to residential mobility of households. The residential mobility literature shows that both the socio-economic and the ethnic mix of the neighbourhood population play a role in residential mobility decisions (van Ham and Clark, 2009; van Ham and Feijten, 2008). Hedman and colleagues (2011) have studied the neighbourhood choice of households in Sweden, using a modelling strategy which could take into account multiple neighbourhood characteristics simultaneously, which is a great advantage over previous studies. They found that households sort into neighbourhoods in a highly structured process where households are most likely to choose neighbourhoods where people live with similar characteristics as themselves - the well-known 'birds of a feather flock together' mechanism (McPherson et al., 2001).

Income was found to be the most important driver of neighbourhood choice, followed by ethnicity. Their study showed that through residential mobility behaviour neighbourhoods are reproduced as low income households tend to move to low income neighbourhoods and high income households move to high income neighbourhoods. It itself this is no surprise as the purchasing power of households determine how much they can pay for housing and how much choice they have on the housing market. As a result high income households have more choice where to live than low income households. The sorting process of households into neighbourhoods is the result of household preferences, resources (income), and the opportunity structure of the housing market (what is available and where) (Hedman et al., 2011).

So while neighbourhoods can be dynamic in their population composition over short periods of time (Van Ham et al., 2013), changes in the socio-economic position of 
neighbourhoods within the overall urban hierarchy tend to be very slow due to the above described reproduction of neighbourhood status (see also Meen et al., 2013; Tunstall, 2016). As a result the socio-economic position of neighbourhoods within the urban hierarchy is generally stable over time over the short term (say 5-10 years). Exceptions are neighbourhoods which are subject to large scale demolition and rebuilding as part of urban renewal policies, and neighbourhoods which experience rapid gentrification processes.

There are few studies which investigate (changing) patterns of segregation over a long period of time (Zwiers et al., 2015). A clear exception is David Hulchanski's (2010) longterm study of the city of Toronto, in which he shows how Toronto has become increasingly polarized in terms of income (Zwiers et al., 2015). The inner-city neighbourhoods that were relatively poor and disadvantaged in the 1970s have become gentrified, and the previously wealthy suburban areas have experienced major downgrading (Van Ham et al., 2013). Using Canadian Census Data for the city of Toronto from 1970 to 2005, Hulchanski (2010) illustrates that a process of spatial (income) polarization has taken place. Compared to 1970, in 2005, the share of high and low- income neighbourhoods has increased while the middle income neighbourhoods are disappearing from the city.

Zwiers and colleagues (2015) have investigated neighbourhood change in cities in the Netherlands over the 1971-2010 period. They found partly similar patterns as in Toronto in that inner cities are increasingly doing well, while some of the suburbs experience downgrading. They found that the initial quality of housing stock in neighbourhoods is an important determinant explaining neighbourhood trajectories. Especially neighbourhoods with a high share of post Second World War (1950-1970) dwellings experienced similar long lowstatus trajectories. Interestingly they found that neighbourhoods subject to explicit and deliberate urban renewal and upgrading policies did not necessarily show upward trajectories. These neighbourhoods appear to be characterized by a persistent low-status, raising questions about the effectiveness of urban renewal programs. Although part of the housing stock in these neighbourhoods was replaced with housing for the middle classes and part of the original population was replaced, many of the original residents who stayed or returned did not benefit socio-economically from the policy initiatives. In addition, such deprived neighbourhoods are generally hardest hit in times of economic crisis, raising questions about future processes of socioeconomic segregation and neighbourhood decline in these neighbourhoods as a result of the recent crisis and consequential government retrenchment (Zwiers et al., 2016).

\section{Intergenerational neighbourhood and income mobility}

Patterns of concentrated poverty in cities are reproduced through the residential mobility of households (Hedman et al., 2011), but also over generations within the same families. It is widely recognised that poverty can be strongly persistent across generations, and that socioeconomic outcomes can be transmitted from parent to child over a long period of time. Table 1 shows a multilevel mixed-effects linear regression model of individual income in the Netherlands, 6 and 12 years after leaving the parental home. We use longitudinal register data from Statistics Netherlands to study a complete cohort of parental home leavers, covering 119,167 individuals nationwide who were followed from 1999 to 2012. The results show that the income of children increases with the income of their parents, and that this effect becomes stronger over time when individuals presumably settle in their occupational careers and income levels. Similarly, we find that the negative significant effect of growing up in a deprived parental neighbourhood on individual income increases over time. These results are in line with sociological literature which has shown that individuals born to poor parents often 
experience less socio-economic mobility throughout life in comparison to those from higher social classes (Blanden et al. 2005; Bloome 2014).

In recent years, this body of research on intergenerational continuity of disadvantage has encouraged the inquiry into further fields of potential parent-to-child outcome transmissions. It is increasingly suggested that intergenerational transmission of wealth and income also has spatial dimensions. Two mechanisms are important here. The first is the intergenerational transmission of living in poverty neighbourhoods, where children growing up in poverty concentration neighbourhoods experience more exposure to such neighbourhoods as adults compared to those who grew up in more affluent neighbourhoods. The second is that these childhood experiences, and subsequent cumulative exposure to poverty neighbourhoods, can have negative effects on individual outcomes such as income and health through so-called neighbourhood effects (for an overview see Ellen \& Turner, 1997; Sampson et al. 2002; Galster 2002, 2012; Friedrichs \& Blasius 2003; Crowder \& South 2003; Wilson, 2012, 1987; van Ham et al. 2014). In order to adequately test (negative) neighbourhood effects researchers have stressed the need for thorough longitudinal research into the impact of neighbourhoods, in order to assess the potential effect of spatial patterns of segregation over time (Sampson et al. 2002; van Ham et al. 2014; de Vuijst et al. 2015).

Only a small number of studies, from the United States, Sweden, and the Netherlands respectively, have investigated the longer term neighbourhood histories of individuals. These studies have shown that growing up in disadvantaged or deprived neighbourhoods often results in long-term exposure to such neighbourhoods over time (Vartanian et al. 2007; Sharkey 2008; Van Ham et al. 2014; de Vuijst et al. 2015). Table 2 shows models of the probability of living in a deprived neighbourhood at 6 and 12 years after leaving the parental neighbourhood for the Netherlands. The results show that even after controlling for individual income and level of education, and parental income, there is intergenerational transmission of living in poverty neighbourhoods: those who grew up in deprived neighbourhoods (quintile 5) are much more likely to live in a similar neighbourhood as their parents compared to those who grew up in more affluent neighbourhoods. Similar results were found for Sweden by van Ham et al., 2014). Tables 3 and 4 show the percentage of time that individuals have spent in each of the five neighbourhood quintiles since leaving the parental home, by parental neighbourhood type, for both Sweden (Table 3) and the Netherlands (Table 4). The results clearly show that those who lived with their parents in the poorest neighbourhoods in both countries (quintile 5) had the longest exposure to poor neighbourhoods in the research period.

In the United States, research showed persistent neighbourhood stratification along economic lines between generations (Vartanian et al. 2007; Sharkey 2008). Furthermore, this persistence was shown to result in intergenerational transmission of racial inequality in individual outcomes, as black Americans were more likely to continuously reside in deprived neighbourhoods, and thus to be exposed to localised disadvantage (Sharkey 2008). In a follow-up study, spatial characteristics were shown to not only affect the neighbourhood outcomes of children, but also those of grandchildren (Sharkey and Elwert 2011). These results thus support the assumption that neighbourhood experiences over the life course are linked to a range of outcomes spanning across several generations, suggesting multigenerational continuity.

In Sweden, researchers tracked, displayed, and analysed the population of the Stockholm metropolitan area, and followed individuals up to almost two decades after leaving the parental home (van Ham et al. 2014). In the Swedish register data, individuals' personal neighbourhood characteristics are recorded on a yearly basis, and spatial deprivation was defined based on the percentage of poor residents within the neighbourhood, i.e. the percentage of neighbours that belong to the $20 \%$ poorest residents of the Stockholm metropolitan area. In the Netherlands, similar national register data were used to follow a 
complete cohort of parental home-leavers for a period of 14 years, and analyse the effect of the parental neighbourhood on the neighbourhood histories of individuals (de Vuijst et al. 2015). This study implemented the same definition of localised deprivation to that used by the Swedish researchers.

In both Sweden and the Netherlands it was found that after leaving the parental home, the characteristics of the parental neighbourhood continue to affect the neighbourhood histories of their children, even after controlling for parental income levels and the personal life attainments of their children. Furthermore, while spatial concentrations of ethnic minority groups within Swedish and Dutch society are not directly comparable to American 'black neighbourhoods', intergenerational neighbourhood patterns were still shown to be much stronger for ethnic minorities than for other groups (van Ham et al. 2014; de Vuijst et al. 2015). In the Netherlands, additional analyses showed that individuals from a deprived parental neighbourhood have a higher chance of discontinuing these intergenerational patterns of spatial deprivation when they attain degrees in higher education over time. Conversely, however, discontinuation is shown to be less prevalent for individuals from ethnic minority groups (de Vuijst et al. 2015).

Figure 3 shows sequence plots of the neighbourhood histories of individuals. Each horizontal line is the neighbourhood history of an individual. As the colour of the line changes, the individual moved to another neighbourhood quintile (see also van Ham et al., 2014 and de Vuijst et al., 2015 for more information and detail). Sequence plots Ia and Ib show for Sweden and the Netherlands respectively the neighbourhood histories of children who lived in the most affluent neighbourhoods (quintile 1) with their parents. This can be seen because the first year in the plot is blue (the least deprived neighbourhoods). Figure IIa and IIb show the sequence plots of those who lived with their parents in the most deprived (grey) neighbourhoods. The difference between I and II is striking in that those who lived with their parents in the most deprived neighbourhoods show a lot more grey in their neighbourhood histories. With other words, after leaving the parental home, those from the most deprived neighbourhoods are much more likely to live in deprived neighbourhoods comparted to those from more affluent neighbourhoods. Figures IIIa and IIIb show the same information for children from non-western ethnic minorities who grew up in the most deprived neighbourhoods. Here the differences with those from the most affluent neighbourhoods is even more striking: more than one third of ethnic minority kids from the most deprived neighbourhoods end up in similar neighbourhoods when they are adults.

There are large differences between the USA, The Netherlands and Sweden with regard to their societal and political structure and organisation, including their welfare systems. Furthermore, the data used and the neighbourhood definitions differ between the studies described. Nevertheless, the above findings do suggest that one's neighbourhood outcomes in life are strongly path dependent; 'enclosed' as it were, in past residential experiences, which span across generations (and societies) through childhood experiences in the parental home.

As mentioned at the start of section 5, another important mechanism is that these childhood experiences, and subsequent cumulative exposure to poverty neighbourhoods, can have negative effects on individual outcomes such as income and health through so-called neighbourhood effects. The model in Table 1 shows that for the Netherlands the parental neighbourhood has an effect on income earned later in life: children who grew up in a low income neighbourhood (quintile 5) have a lower income later in life (6 and 12 years after leaving the parental home) than those who grew up in more affluent neighbourhoods. The results are also in line with what was found in Sweden (Hedman et al., 2011). 
Table 1 Multilevel models on intergenerational income transmission in the Netherlands, 6 and 12 years after leaving the parental home

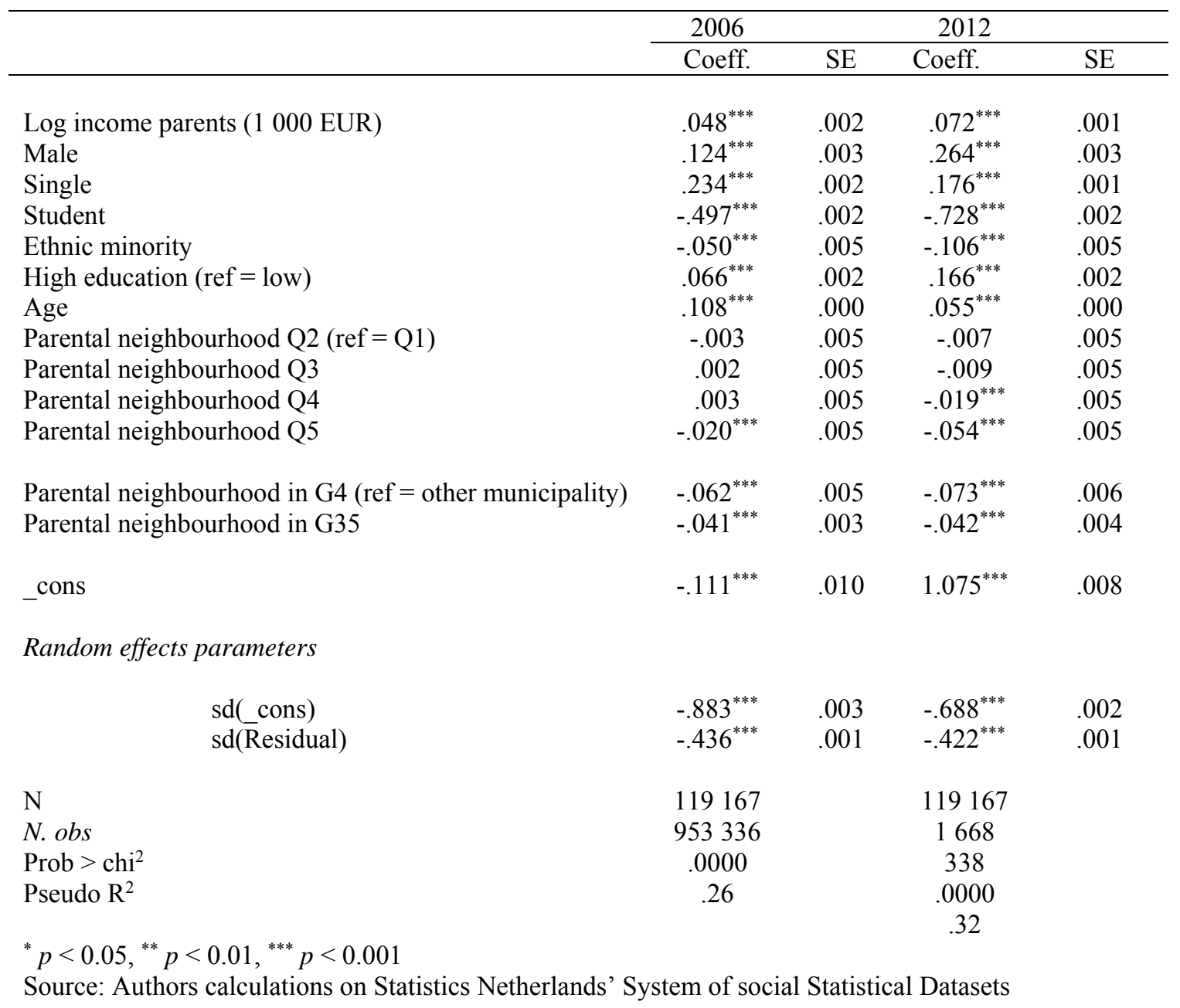


Table 2 Multilevel logit models on living in a deprived neighbourhood in the Netherlands (quintile 5), 6 and 12 years after leaving the parental home

\begin{tabular}{|c|c|c|c|c|c|c|c|c|c|c|c|c|}
\hline \multirow[b]{3}{*}{ Parental neighbourhood $\mathrm{Q} 2(\mathrm{ref}=\mathrm{O} 1)$} & \multicolumn{6}{|c|}{2006} & \multicolumn{6}{|c|}{2012} \\
\hline & \multicolumn{2}{|c|}{ model 1} & \multicolumn{2}{|c|}{ model 2} & \multicolumn{2}{|c|}{ model 3} & \multicolumn{2}{|c|}{ model 1} & \multicolumn{2}{|c|}{ model 2} & \multicolumn{2}{|c|}{ model 3} \\
\hline & $.098^{* *}$ & .032 & $.094^{* *}$ & .033 & $.098^{* *}$ & .033 & $.127^{* * *}$ & .031 & $.124^{* * *}$ & .031 & $.127^{* * *}$ & .031 \\
\hline Parental neighbourhood Q3 & $266^{* * *}$ & .031 & $.264^{* * *}$ & .032 & $266^{* * *}$ & .032 & $.304^{* * *}$ & .030 & $.302^{* * *}$ & .030 & $.303^{* * *}$ & .030 \\
\hline Parental neighbourhood Q4 & $.620^{* * *}$ & .031 & $.620^{* * *}$ & .031 & $.628^{* * *}$ & .031 & $.650^{* * *}$ & .029 & $.649^{* * *}$ & .029 & $.655^{* * *}$ & .029 \\
\hline Parental neighbourhood Q5 & $3.197^{* * *}$ & .030 & $3.626^{* * *}$ & .032 & $3.591^{* * *}$ & .033 & $2.785^{* * *}$ & .029 & $3.199^{* * *}$ & .030 & $3.187^{* * *}$ & .031 \\
\hline Male & $207^{* * *}$ & .018 & $210^{* * *}$ & .018 & $.208^{* * *}$ & .018 & $.198^{* * *}$ & .017 & $201^{* * *}$ & .017 & $201^{* * *}$ & .017 \\
\hline Single & $.580^{* * *}$ & .009 & $.585^{* * *}$ & .009 & $.584^{* * *}$ & .009 & $.540^{* * *}$ & .007 & $.547^{* * *}$ & .007 & $.545^{* * *}$ & .007 \\
\hline Ethnic minority & $.424^{* * *}$ & .030 & $.424^{* * *}$ & .030 & $.191^{* * *}$ & .041 & $.614^{* * *}$ & .029 & $.612^{* * *}$ & .029 & $.308^{* * *}$ & .038 \\
\hline High education $($ ref $=$ low $)$ & $-.112^{* * *}$ & .011 & $.301^{* * *}$ & .013 & $.299^{* * *}$ & .013 & $-.434^{* * *}$ & .009 & $-.086^{* * *}$ & .010 & $-.122^{* * *}$ & .011 \\
\hline Log income (1 000 EUR) & $-.036^{* * *}$ & .005 & $-.037^{* * *}$ & .005 & $-.036^{* * *}$ & .005 & $-.157^{* * *}$ & .004 & $-.161^{* * *}$ & .004 & $-.158^{* * *}$ & .004 \\
\hline Rent (ref = homeowner) & $.418^{* * *}$ & .009 & $.417^{* * *}$ & .009 & $.418^{* * *}$ & .009 & $.419^{* * *}$ & .007 & $.415^{* * *}$ & .007 & $.419^{* * *}$ & .007 \\
\hline Age & $-.091^{* * *}$ & .002 & $-.091^{* * *}$ & .002 & $-.091^{* * *}$ & .002 & $-.059^{* * *}$ & .001 & $-.059^{* * *}$ & .001 & $-.058^{* * *}$ & .001 \\
\hline Log income parents (1 000 EUR) & -.001 & .017 & -.004 & .017 & .001 & .017 & $-.143^{* * *}$ & .016 & $-.148^{* * *}$ & .016 & $-.140^{* * *}$ & .016 \\
\hline Parental Q5*high education & & & $-1.377^{* * *}$ & .024 & $-1.491^{* * *}$ & .025 & & & $-1.190^{* * *}$ & .019 & $-1.305^{* * *}$ & .020 \\
\hline Parental Q5*ethnic minority & & & & & $.340^{* * *}$ & .063 & & & & & $.226^{* * *}$ & .060 \\
\hline High education*ethnic minority & & & & & -.019 & .051 & & & & & $.434^{* * *}$ & .039 \\
\hline Parental Q5*high education*ethnic minority & & & & & $.982^{* * *}$ & .079 & & & & & $.753^{* * *}$ & .061 \\
\hline _cons & $-1.603^{* * *}$ & .073 & $-1.725^{* * *}$ & .074 & $-1.741^{* * *}$ & .074 & $-1.391^{* * *}$ & .064 & $-1.489^{* * *}$ & .064 & $-1.515^{* * *}$ & .064 \\
\hline $\mathrm{N}$ & 119167 & & 119167 & & 119167 & & 119167 & & 119167 & & 119167 & \\
\hline N. obs & 953336 & & 953336 & & 953336 & & 1668338 & & 1668338 & & 1668338 & \\
\hline Prob $>$ chi $^{2}$ & .0000 & & .0000 & & .0000 & & .0000 & & .0000 & & .0000 & \\
\hline Nagelkerke $R^{2}$ & .066 & & .073 & & .074 & & .065 & & .070 & & .071 & \\
\hline
\end{tabular}

$* \mathrm{p}<0.05, * * \mathrm{p}<0.01, * * * \mathrm{p}<0.001$

Source: Authors calculations on Statistics Netherlands' System of social Statistical Datasets, from De Vuijst et al., 2015 
Table 3 Residence in neighbourhood quintiles (1991-2008) by parental neighbourhood quintile (1990) in Sweden

\begin{tabular}{|c|c|c|c|c|c|}
\hline \multirow{2}{*}{$\begin{array}{l}\text { Parental neighbourhood } \\
\text { quintile in } 1990\end{array}$} & \multicolumn{5}{|c|}{ Exposure to deprived neighbourhood over the measurement period 1991-2008 } \\
\hline & Quintile 1 & Quintile 2 & Quintile 3 & Quintile 4 & Quintile 5 \\
\hline Quintile 1 & 17.9 & 14.9 & 16.0 & 20.6 & 30.6 \\
\hline Quintile 2 & 16.3 & 14.7 & 16.9 & 21.9 & 30.3 \\
\hline Quintile 3 & 13.1 & 12.8 & 16.9 & 23.6 & 33.6 \\
\hline Quintile 4 & 10.6 & 10.9 & 15.7 & 24.4 & 38.3 \\
\hline Quintile 5 & 8.9 & 9.0 & 13.1 & 20.3 & 48.8 \\
\hline
\end{tabular}

Note: Unless otherwise indicated, values are reported in percentages.

Source: van Ham et al., 2014, calculations on GeoSweden dataset.

Table 4 Residence in neighbourhood quintiles (2000-2012) by parental neighbourhood quintile (1999) in the Netherlands

\begin{tabular}{|c|c|c|c|c|c|}
\hline Parental neighbourhood & \multicolumn{5}{|c|}{ Exposure to deprived neighbourhood over the measurement period 2000-2012 } \\
\hline & Quintile 1 & Quintile 2 & Quintile 3 & Quintile 4 & Quintile 5 \\
\hline Quintile 1 & 38.6 & 18.9 & 15.2 & 13.2 & 14.2 \\
\hline Quintile 2 & 22.7 & 30.2 & 17.2 & 14.8 & 15.1 \\
\hline Quintile 3 & 20.0 & 18.0 & 28.6 & 17.0 & 16.3 \\
\hline Quintile 4 & 17.7 & 16.3 & 17.5 & 29.1 & 19.4 \\
\hline Quintile 5 & 15.1 & 13.9 & 15.4 & 17.9 & 37.8 \\
\hline
\end{tabular}

Note: Unless otherwise indicated, values are reported in percentages.

Source: Authors calculations on Statistics Netherlands' System of social Statistical Datasets, from De Vuijst et al., 2015. 
Figure 3 Sequence plots on patterns of individual neighbourhood histories of those leaving the parental home, by parental neighbourhood quintiles (1: lowest poverty concentration, and 5: highest poverty concentration). Plots I a \& b, Sweden (Stockholm metro area) and the Netherlands respectively, low parental neighbourhood poverty. Plots II a \& b, high parental neighbourhood poverty. Plots III a \& b, high parental neighbourhood poverty and ethnic minority.
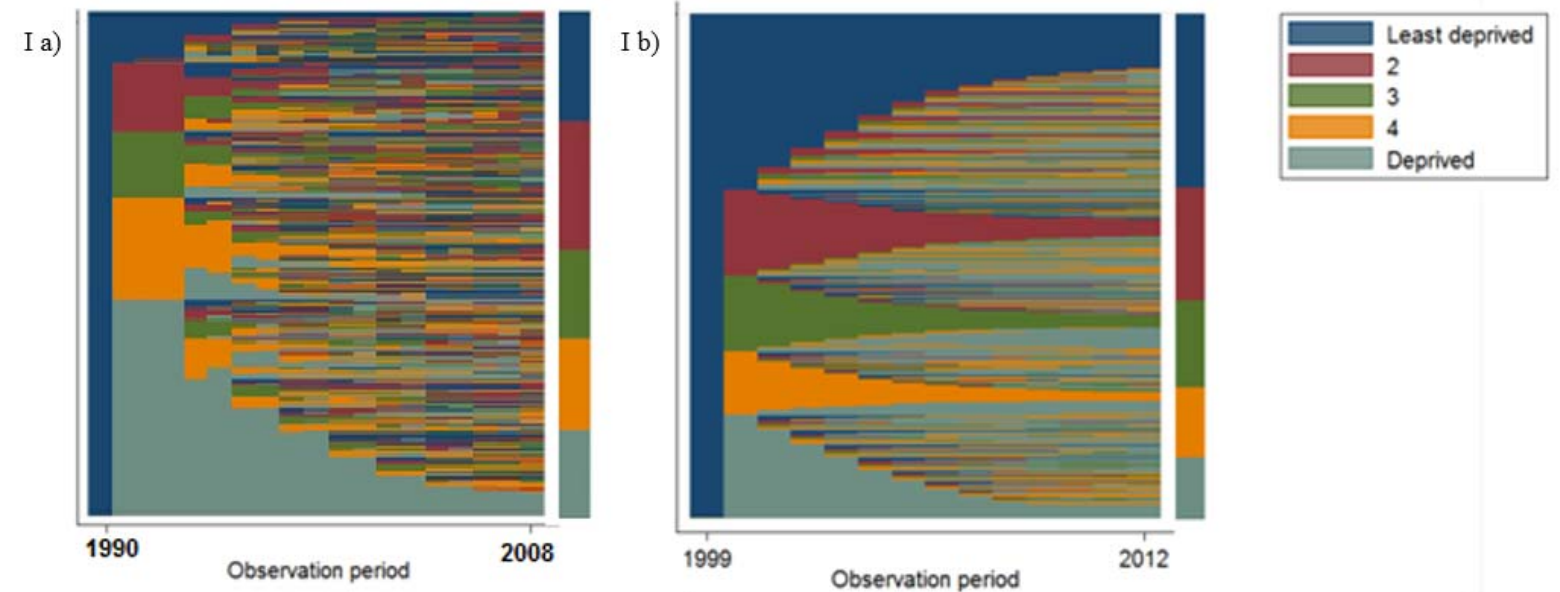

II a)

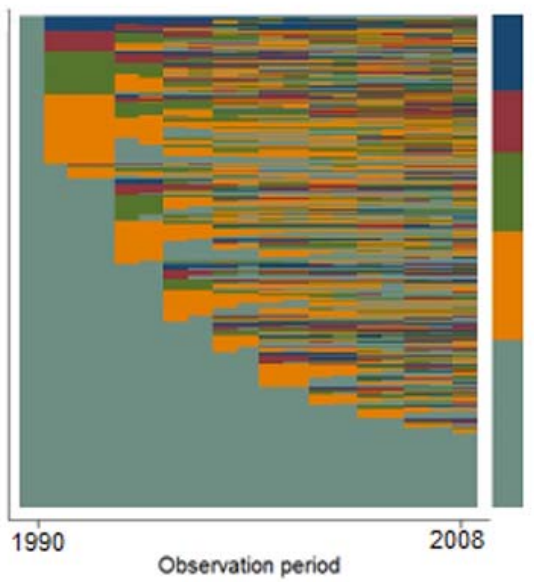

II b)
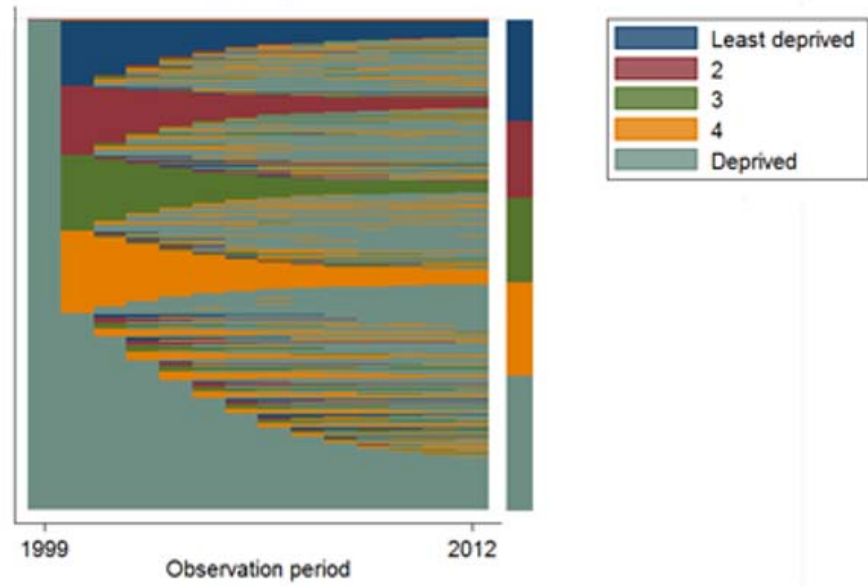

III a)
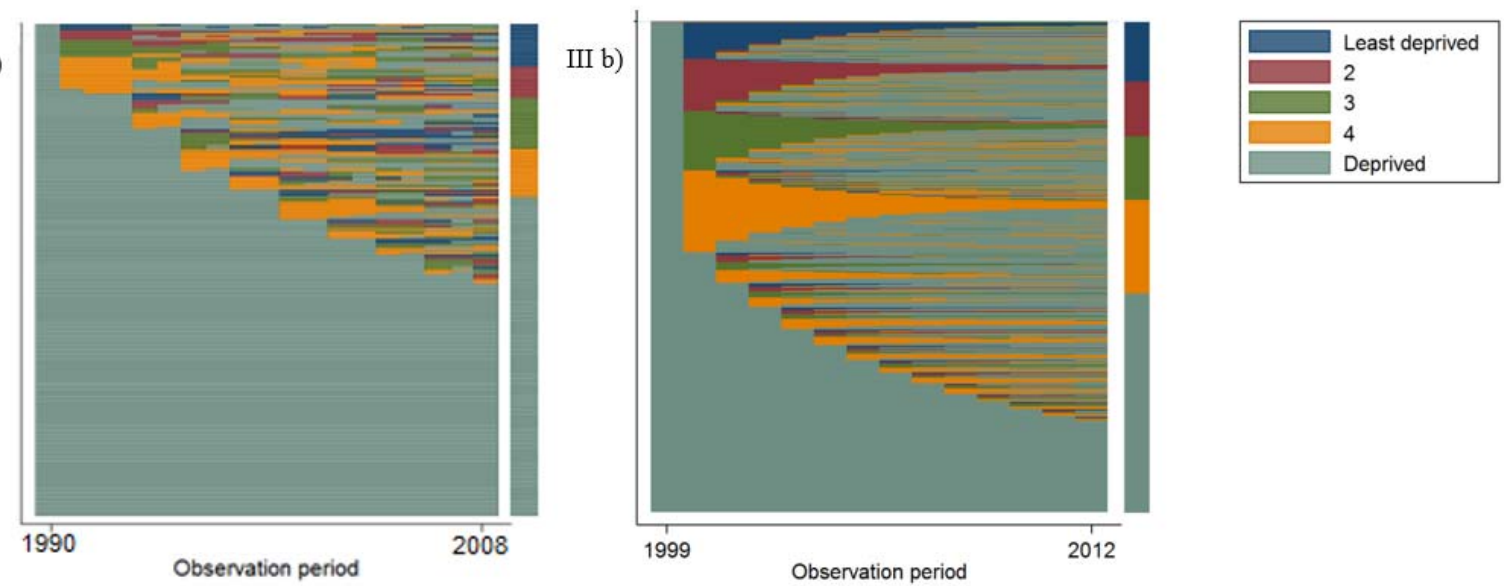

Source Netherlands data: Authors calculations on Statistics Netherlands' System of social Statistical Datasets.

Source Swedish data: GeoSweden dataset from van Ham et al., 2014.

Source Netherlands data: Statistics Netherlands' System of social Statistical Datasets, from De Vuijst et al., 2015. 


\section{Conclusion}

Socio-economic segregation is increasing in European cities, and although segregation levels in Europe are still relatively low compared to other regions in the world, governments are worried about the social sustainability of cities. The main cause of increasing segregation by income is increasing inequality and poverty in Europe. This is related to the restructuring of the labour market in the last decades, and the changing nature of European welfare states, although these welfare states have also cushioned the effects of structural changes.

The effects of increasing inequality on the spatial organisation of cities is slow and often takes place with a considerable time lag (say 10 years). It can therefore be expected that the effects of the economic crisis since 2008 are not yet fully visible in cities. The urban mosaic of neighbourhoods by socio-economic status changes very slowly. The main reason is that the housing stock is very stable over time and the residential mobility behaviour of households reproduces neighbourhoods. Reproduction of neighbourhoods also takes place over generations, where children often end up in very similar neighbourhoods as where they grew up.

Segregation is not necessarily a problem as many households choose to live in neighbourhoods with very similar people as themselves. Segregation becomes a problem when there are large concentrations of poverty where people get cut off from mainstream society and from opportunities. Policies aiming at creating more socio-economically mixed neighbourhoods might have positive effects on neighbourhoods as low income households are replaced by more affluent households. But such measures do not change the underlying causes of segregation by income.

To really make a change, policy should focus on people and not on areas, including stimulating intra-urban mobility through efficient public transport networks to improve access to jobs and services. People-based policy measures that focus on creating opportunities for people through investments in education and training are especially important. Such measures take a long time to have an effect on inequality and poverty.

\section{Acknowledgements}

This working paper was commissioned by the OECD and part of the text was used for the 2016 OECD report Making Cities Work for All. Data and Actions for Inclusive Growth (https://www.oecd.org/regional/making-cities-work-for-all-9789264263260-en.htm). The research leading to these results has received funding from the European Research Council under the European Union's Seventh Framework Programme (FP/2007-2013) / ERC Grant Agreement n. 615159 (ERC Consolidator Grant DEPRIVEDHOODS, Socio-spatial inequality, deprived neighbourhoods, and neighbourhood effects); from the Marie Curie programme under the European Union's Seventh Framework Programme (FP/2007-2013) / Career Integration Grant n. PCIG10-GA-2011-303728 (CIG Grant NBHCHOICE, Neighbourhood choice, neighbourhood sorting, and neighbourhood effects), from the Estonian Research Council (Institutional Research Grant IUT2-17 on Spatial Population Mobility and Geographical Changes in Urban Regions); and from the Estonian Science Foundation (Grant No. 8774 and 9247). 


\section{References}

Andersson, R \& A Kährik 2016, 'Widening gaps: segregation dynamics during two decades of economic and institutional change in Stockholm' in Socio-Economic Segregation in European Capital Cities. East meets West, eds T Tammaru, S Marcińczak, M van Ham \& S Musterd, Routledge, London.

Atkinson, R., Kintrea K. (2002), Area Effects: What do they mean for British Housing and Regeneration Policy? European Journal of Housing Policy, 2: 147-166.

Bērziņš, M \& Krišjāne, Z 2016, 'Occupation and ethnicity: patterns of residential segregation in Riga two decades after socialism' in Socio-Economic Segregation in European Capital Cities. East meets West, eds $\mathrm{T}$ Tammaru, S Marcińczak, M van Ham \& S Musterd, Routledge, London.

Blanden, J., Gregg, P., \& Machin, S. (2005). Intergenerational Mobility in Europe and North America. London. London School of Economics. Centre for Economic Performance.

Bloome, D. (2014). Racial Inequality Trends and the Intergenerational Persistence of Income and Family Structure. American Sociological Review, 79(6), 1196-1225, doi: $10.1177 / 0003122414554947$.

Chrisafis A. (2015) 'Nothing's changed': 10 years after French riots, banlieues remain in crisis. The Guardian 22 October 2015.

Clark, W.A.V. (1991) Residential preferences and neighborhood racial segregation - a test of the Schelling segregation model, Demography, 28, pp. 1-19

Crowder, K., \& South, S. J. (2003). Neighborhood distress and school dropout: the variable significance of community context. Social Science Research, 32(4), 659-698, doi:http://dx.doi.org/10.1016/S0049-089X(03)00035-8.

De Vuijst, E., van Ham, M. \& Kleinhans, R. (2015). The Moderating Effect of Higher Education on Intergenerational Spatial Inequality. IZA Discussion paper No. 9557, http://ftp.iza.org/dp9557.pdf

Ellen, I. G., \& Turner, M. A. (1997). Does neighborhood matter? Assessing recent evidence. Housing Policy Debate, 8(4), 833-866, doi:10.1080/10511482.1997.9521280.

Esping-Andersen G. (1990) The Three Worlds of Welfare Capitalism. Cambridge: Polity Press.

Feijten P.M. and van Ham M. (2009) Neighbourhood change... reason to leave? Urban Studies 46, 2103-2122.

Florida R. (2015) Economic Segregation and Inequality in Europe's Cities. These are not just American problems. Citylab, 16 November 2015.

Friedrichs, J. r., \& Blasius, J. r. (2003). Social norms in distressed neighbourhoods: testing the Wilson hypothesis. Housing Studies, 18(6), 807-826, doi: $10.1080 / 0267303032000135447$.

Galster, G. (2002). An economic efficiency analysis of deconcentrating poverty populations. Journal of Housing Economics, 11(4), 303-329, doi:http://dx.doi.org/10.1016/S10511377(02)00122-5.

Galster, G. C. (2012). The Mechanism(s) of Neighbourhood Effects: Theory, Evidence, and Policy Implications. In M. van Ham, D. Manley, N. Bailey, L. Simpson, \& D. Maclennan (Eds.), Neighbourhood Effects Research: New Perspectives (pp. 23-56): Springer Netherlands.

Giesen P. (2015) Met de stenen gaat het goed, met de mensen een stuk minder. Volkskrant 26 October 2015.

Hamnett C. (1994) Social polarization in global cities: theory and evidence Urban Studies, 31, $401-425$. 
Hedman L., van Ham M. and Manley D. (2011) Neighbourhood choice and neighbourhood reproduction. Environment and Planning A 43, 1381-1399.

Hedman L., Manley D., van Ham M. \& Östh J. (2015) Cumulative exposure to disadvantage and the intergenerational transmission of neighbourhood effects. Journal of Economic Geography 15(1), 195-215.

Hulchanski, D. (2010) The three cities within Toronto: Income polarization among Toronto's neighbourhoods, 1970-2005. Cities Centre, University of Toronto, Ontario.

Kearns, A., Parkinson, M. (2001), The Significance of Neighbourhood, Urban Studies, 38: 2103-2110.

Leal, J \& Sorando D 2016, 'Economic crisis, social change and segregation processes in Madrid' in Socio-Economic Segregation in European Capital Cities. East meets West, eds T Tammaru, S Marcińczak, M van Ham \& S Musterd, Routledge, London.

Marcińczak, S, Musterd, S, van Ham, M \& Tammaru, T 2016, 'Inequality and rising levels of socio-economic segregation: Lessons from a pan-European comparative study' in Socio-Economic Segregation in European Capital Cities. East meets West, eds T Tammaru, S Marcińczak, M van Ham \& S Musterd, Routledge, London.

McPherson, M., Smith-Lovin, L. \& Cook, J.M. (2001) Birds of a feather: Homophily in social networks, Annual Review of Sociology, 27, 415-44.

Meen, G., C. Nygaard and J. Meen (2013) The causes of long-term neighbourhood change. In Ham, M. V., Manley, D., Bailey, N., Simpson, L. \& Maclennan, D. (eds.) Understanding neighbourhood dynamics: New insights for neighbourhood effects research. Springer, Dordrecht.

Musterd, S \& van Gent, W 2016, 'Changing welfare context and income segregation in Amsterdam and its metropolitan area' in Socio-Economic Segregation in European Capital Cities. East meets West, eds $\mathrm{T}$ Tammaru, S Marcińczak, M van Ham \& S Musterd, Routledge, London.

Musterd S. \& Ostendorf W. (Eds) (1998) Urban segregation and the welfare state: Inequality and exclusion in western cities, London, Routledge.

Musterd, S. (2002), Response: Mixed housing policy: A European (Dutch), perspective, Housing Studies, 17: 139-143.

OECD (2008) Growing Unequal? Income Distribution and Poverty in OECD Countries, OECD Publishing, Paris. http://dx.doi.org/10.1787/9789264044197-en

OECD (2015) In It Together: Why Less Inequality Benefits All, OECD Publishing, Paris. http://dx.doi.org/10.1787/9789264235120-en

Piketty T. (2013) Capital in the $21^{\text {st }}$ Century, Harvard University Press, Harvard.

Sampson, R. J., Morenoff, J. D., \& Gannon-Rowley, T. (2002). Assessing "Neighborhood Effects": Social Processes and New Directions in Research. Annual Review of Sociology, Vol.28, pp. 443-478, doi:10.2307/3069249.

Sassen S. (1991) The Global City: New York, London, Tokyo, Princeton University Press, Princeton.

Schelling, T.C. (1969) Models of segregation, The American Economic Review, 59, pp. 488493

Schelling, T.C. (1971) Dynamic models of segregation, Journal of mathematical sociology, 1, pp. 143-186.

Sharkey, P. (2008). The Intergenerational Transmission of Context. American Journal of Sociology, Vol. 113(4), pp. 931-969, doi: 10.1086/522804

Sharkey, P., \& Elwert, F. (2011). The legacy of disadvantage: Multigenerational neighborhood effects on cognitive ability. AJS; American journal of sociology, Vol. 116(6), 1934. 
Tammaru T., Marcińczak S., van Ham M. \& Musterd S. (eds) (2016) Socio-Economic Segregation in European Capital Cities: East Meets West. Routledge: Oxford.

Tammaru, T, Musterd, S, van Ham, M \& Marcińczak, S, 2016, 'A multi-factor approach to understanding socio-economic segregation in European capital cities' in Socio-Economic Segregation in European Capital Cities. East meets West, eds T Tammaru, S Marcińczak, $M$ van Ham \& S Musterd, Routledge, London.

Tammaru, T, Kährik, A, Mägi, K Novák, J \& Leetmaa, K 2016, 'The 'market experiment': Increasing socio-economic segregation in the inherited bi-ethnic context of Tallinn' in Socio-Economic Segregation in European Capital Cities. East meets West, eds T Tammaru, S Marcińczak, M van Ham \& S Musterd, Routledge, London.

Tunstall, R. (forthcoming) Are neighbourhoods dynamic or are they slothful? The limited prevalence and extent of change in neighbourhood socio-economic status, and its implications for regeneration policy. Urban Geography.

Valatka, V, Burneika, D \& Ubarevičienè R, 2016, 'Large social inequalities and low levels of socio-economic segregation in Vilnius' in Socio-Economic Segregation in European Capital Cities. East meets West, eds $\mathrm{T}$ Tammaru, S Marcińczak, M van Ham \& S Musterd, Routledge, London.

van Ham M. and Clark W.A.V (2009) Neighbourhood mobility in context: household moves and changing neighbourhoods in the Netherlands. Environment and Planning A 41, 1442-1459.

van Ham M. and Feijten P.M. (2008) Who wants to leave the neighbourhood? The effect of being different from the neighbourhood population on wishes to move. Environment and Planning A 40(5), 1151-1170.

van Ham M., Manley D., Bailey N., Simpson L. \& Maclennan D. (eds) (2012) Neighbourhood Effects Research: New Perspectives. Springer: Dordrecht.

van Ham, M., Hedman, L., Manley, D., Coulter, R., \& Östh, J. (2014). Intergenerational transmission of neighbourhood poverty: an analysis of neighbourhood histories of individuals. Transactions of the Institute of British Geographers, 39(3), 402-417, doi:10.1111/tran.12040.

Van Ham, M., D. Manley, N. Bailey, L. Simpson and D. Maclennan (2013) Understanding neighborhood dynamics: New insights for neighbourhood effects research. In M. Van Ham, D. M., N. Bailey, L. Simpson, \& D. Maclennan (ed.) Understanding neighbourhood dynamics: New insights for neighbourhood effects research. Springer, Dordrecht.

van Ham M., Tammaru T., Marcińczak S. \& Musterd S. (2016) Urban Segregation. In the European Cities Report. EU.

van Ham M. \& Tammaru T. (2016) New perspectives on ethnic segregation over time and space. A domains approach. Urban Geography.

Vartanian, T. P., Walker Buck, P., \& Gleason, P. (2007). Intergenerational NeighborhoodType Mobility: Examining Differences between Blacks and Whites. Housing Studies, 22(5), 833-856, doi:10.1080/02673030701474792.

Wessel, T 2016, 'Economic segregation in Oslo: polarisation as a contingent outcome' in Socio-Economic Segregation in European Capital Cities. East meets West, eds $\mathrm{T}$ Tammaru, S Marcińczak, M van Ham \& S Musterd, Routledge, London.

Wilson, W. J. (2012 [1987]). The truly disadvantaged: The inner city, the underclass, and public policy. Chicago: University of Chicago Press.

Zwiers M., Kleinhans K. \& van Ham M. (2015) Divided cities: increasing socio-spatial polarization within large cities in the Netherlands. IZA Discussion Paper No. 8882 (www.iza.org). 
Zwiers M., Bolt G., van Ham M. \& van Kempen R. (2016): The global financial crisis and neighborhood decline, Urban Geography, DOI: 10.1080/02723638.2015.1101251 